\title{
AKTIVITAS ANTIOKSIDAN DAN SITOTOKSISITAS IN VITRO EKSTRAK METANOL BUAH NANAS (Ananas comosus) PADA SEL KANKER PAYUDARA T-47D
}

\section{Antioxidant and Cytotoxic In Vitro Activities of Ananas comosus Methanol Extract in T-47D Breast Cancer Cell Line}

\author{
Rahma Micho Widyanto ${ }^{1 *}$, Johanna Angkasa Putri ${ }^{1}$, Yosfi Rahmi ${ }^{1}$, Wahyu Diah Proborini ${ }^{2}$, \\ Budi Utomo ${ }^{3}$ \\ 1) Jurusan Gizi, Fakultas Kedokteran Universitas Brawijaya Malang \\ Jl. Veteran, Malang 65145 \\ 2) Jurusan Teknik Kimia, Fakultas Teknik Universitas Tribhuwana Tunggadewi \\ Jl. Telaga Warna Tlogomas Malang, 65144 \\ 3) Fakultas Peternakan, Universitas Nusantara PGRI Kediri \\ JI. KH Achmad Dahlan Mojoroto Kediri, 64112 \\ *Penulis Korespondensi, Email: micho@ub.ac.id
}

\begin{abstract}
ABSTRAK
Jenis kanker yang paling umum ditemui di rumah sakit di Indonesia adalah kanker payudara $(28.7 \%)$ disusul kanker serviks (12.8\%). Salah satu upaya terapi pendukung untuk kanker adalah melalui konsumsi buah-buahan. Buah Nanas (Ananas comosus) banyak diteliti potensinya sebagai antikanker. Buah nanas merupakan sumber antioksidan dan berfungsi sebagai agen antikanker lewat mekanisme aktivasi apoptosis sel kanker serta penghambatan aktivitas reseptor tirosin kinase. Tujuan penelitian ini untuk mengamati aktivitas antioksidan dan sitotoksisitas ekstrak metanol buah nanas terhadap sel T-47D secara In Vitro. Proses ekstraksi daging buah nanas dilakukan dengan memakai pelarut metanol, selanjutnya diuji aktivitas antioksidan dengan DPPH dan sitotoksisitas menggunakan uji MTT pada sel kanker payudara T-47D. Nilai IC $_{50}$ aktivitas antioksidan menunjukkan hasil sebesar $1549.88 \mu \mathrm{g} / \mathrm{ml}$ dan $\mathrm{IC}_{50}$ untuk uji sitotoksisitas sebesar 741.46 $\mu \mathrm{g} / \mathrm{ml}$. Hasil penelitian menunjukkan ekstrak metanol buah nanas mempunyai aktivitas antioksidan yang sangat lemah dan sitotoksisitas moderat terhadap sel T-47D secara in vitro sehingga bisa sebagai agen kemopreventif.
\end{abstract}

Kata kunci: Ananas comosus, Antioksidan, Kanker payudara, Sel T-47D, Sitotoksisitas

\section{ABSTRACT}

The most cancer type found in hospitals in Indonesia is breast cancer (28.7\%) followed by cervical cancer (12.8\%). One therapeutic aid for cancer is to consume fruits. Pineapple (Ananas comosus) is widely recommended as an anticancer potential. Pineapple is a source of antioxidants that have mechanisms of activation of cancer cell apoptosis pathways and inhibition of tyrosine kinase receptor activity. The purpose of this study is to observe the antioxidant activity and cytotoxicity of pineapple fruit methanol extract on T-47D cells. Pineapple flesh extraction process was carried out using methanol solvent, then were assessed for antioxidant activity using DPPH and cytotoxicity using MTT assay. The result of $I_{50}$ antioxidant activity and cytotoxicity assay showed $1549.88 \mu \mathrm{g} / \mathrm{ml}$ and $741.46 \mu \mathrm{g} / \mathrm{m}$, respectively. The conclusion that the pineapple methanol extract had very weak antioxidant activity and moderate cytotoxicity against T-47D cell lines in vitro so that it can be as a chemopreventive agent.

Keywords: Ananas comosus, Antioxidant, Breast cancer, Cytotoxicity, T-47D cell line 


\section{PENDAHULUAN}

Kanker merupakan penyakit akibat perubahan fungsi dan struktur sel sehingga menyebabkan proses abnormalitas pada pembelahan sel (Kelvin dan Tyson, 2011). Pembelahan sel kanker dipicu berbagai faktor yang menyebabkan perubahan ekspresi gen sehingga timbul gangguan proliferasi yang tidak terkontrol, berinvasi dan metastase ke jaringan dan organ lain (Kurniasari dkk., 2017).

Satu dari enam kematian di dunia terjadi akibat penyakit kanker dan merupakan penyebab kedua untuk jumlah kematian tertinggi di dunia dengan korban kematian sekitar 9.6 juta manusia (WHO, 2018). Kejadian kanker di Indonesia pada 2013-2018 adalah 14 per 1000 naik sebesar $28.6 \%$ menjadi 1.8 per 1000 populasi. Kanker payudara menempati urutan pertama dengan prevalensi 40 per 100000 meningkat dari tahun 2002 dengan angka 26 per 1000 (IARC, 2012). Jenis kanker yang paling banyak ditemukan pada pasien di rumah sakit di Indonesia adalah kanker payudara (28.7\%) kemudian kanker serviks $(12.8 \%)$ (Kemenkes RI, 2018).

Salah satu upaya terapi pendukung untuk mengatasi penyakit kanker adalah melalui bahan makanan, utamanya buah-buahan. Terdapat keterkaitan antara konsumsi buah dengan resiko penurunan kanker payudara (Aune dkk., 2012). Buah Nanas (Ananas comosus) banyak diteliti potensinya sebagai antikanker. Buah nanas merupakan sumber antioksidan dari berbagai kandungan fitokimia senyawa fenolik dan flavonoid, dimana antioksidan bekerja dengan menangkap radikal bebas, sehingga dapat menghambat proliferasi sel kanker dan menjadi agen antikanker (Hatam dkk., 2013; Pambudi, 2017; Lu dkk., 2014; Ferreira dkk., 2016).

Tujuan dari penelitian ini adalah mengevaluasi potensi aktivitas antioksidan dan antikanker ekstrak metanol buah nanas (Ananas comosus). Pemilihan pelarut metanol dikarenakan lebih efisien dalam mengekstrak senyawa fenolik dengan berat molekul yang rendah seperti asam fenolik, dimana asam fenolik merupakan senyawa fenolik utama yang berada pada nanas (Rasheed dkk., 2012). Pengukuran aktivitas antioksidan menggunakan metode DPPH serta uji antikanker menggunakan metode MTT assay pada sel kanker payudara T-47D secara In Vitro.

\section{BAHAN DAN METODE}

\section{Bahan}

Daging buah nanas (Ananas comosus) yang berasal dari pasar tradisional di Pujon, Jawa Timur, Indonesia, dipilih sebagai sampel. Bahan untuk pembuatan ekstrak adalah metanol dan aquades. Uji antioksidan memakai DPPH, Vitamin C (Merck), DMSO (sigma). Uji sitotoksisitas menggunakan sel kanker payudara T-47D (Lab Kultur Sel LAPTIAB BPPT PUSPIPTEK Serpong), medium RPMI-1640 (Gibco), MTT (Sigma), Fetal Bovine Serum (Gibco), Trypsin-EDTA (Gibco), Phosphate Buffer Saline (Sigma), trypan blue (Gibco), HCl (Sigma), Sodium Dodecyl Sulfate (Sigma).

\section{Alat}

Alat yang digunakan adalah tabung erlenmeyer [lwaki], gelas beaker [Schott Durant], tabung mikrosentrifus $1.5 \mathrm{ml}$ [Bio-Rad], tabung $0.2 \mathrm{ml}$ [Bio-Rad], tips $(0.1-20,20-200,200-$ 1000) $\mu \mathrm{l}$ [Bio-Rad], pipet mikro (0.1-2, 2-20, 20-200, 200-1000) $\mu \mathrm{l}$ [Bio-Rad], tabung falkon $(15,50) \mathrm{ml}$ [lwaki], cawan petri [Petriq], refrigerator [LG], timbangan $0.02-210 \mathrm{~g}$ [AND GF200], vortex [Gemmy Industrial], pipette pump [Bel art Alla], microcentrifuge [Sorvall], membrane filter $0.2 \mu \mathrm{m}$ dan $0.45 \mu \mathrm{m}$ [Pall], syringe [Dong Shin GNM], kamera digital [Nikkon,Olympus], laminar air flow cabinet [Gelaire ICN Biomedicals], deep freezer -80은 C[Angelantoni Scientifica], oven [Bicasa], cooling bath [Heto], ice maker [Hoshizaki], spectrophotometer [Simadzu], Inkubator $\mathrm{CO}_{2}$ [Memmert]. 


\section{Desain Penelitian}

Penelitian ini menggunakan desain True Experimental Laboratory secara In Vitro. Pengujian aktivitas antioksidan menggunakan 4 seri konsentrasi triplo dengan kontrol positif menggunakan vitamin C. Uji sitotoksisitas menerapkan Post-test Only Control Group Design pada 4 seri konsentrasi triplo dengan kontrol positif menggunakan Cisplatin.

\section{Tahapan Penelitian}

Buah nanas yang digunakan adalah bagian daging buah nanas utuh dengan mahkota, berbobot minimal $300 \mathrm{~g}$, warna kulit buah mulai menguning, bersih dan bebas dari aroma asing. Setelah itu dilakukan ekstraksi menggunakan pelarut metanol menggunakan metode maserasi. Ekstrak metanol selanjutnya diuji aktivitas antioksidan memakai metode DPPH dan uji sitotoksisitas menggunakan MTT assay dengan rentang konsentrasi (125; 250; 500; dan 1000) $\mathrm{\mu g} / \mathrm{ml}$. Kontrol untuk uji antioksidan dan sitotoksisitas masing-masing adalah asam askorbat dan cisplatin. Hasil uji akan dianalisis untuk mengetahui nilai $\mathrm{IC}_{50}$.

\section{Metode}

Pembuatan ekstrak

Pembuatan ekstrak berdasarkan modifikasi dari metode Rejeki dan Ningsih (2010). Sebanyak $100 \mathrm{~g}$ daging buah nanas dihancurkan dan dilakukan maserasi pada $650 \mathrm{ml}$ pelarut metanol pada kondisi suhu ruang. Hasil maserat selanjutnya disentrifugasi dengan kecepatan 8000 rpm selama 15 menit. Supernatan kemudian didestilasi dengan suhu $75-80^{\circ}$ $\mathrm{C}$ hingga mendapatkan ekstrak metanol buah nanas. Steam bath dilakukan hingga tidak tercium bau metanol. Ekstrak metanol buah nanas kemudian akan digunakan sebagai sampel untuk pengujian selanjutnya.

\section{Pengujian aktivitas antioksidan}

Uji aktivitas antioksidan pada ekstrak metanol buah nanas menggunakan modifikasi dari metode Primurdia dan Kusnadi (2014); Widowati dkk. (2015). Sebanyak 2 mg DPPH dilarutkan menggunakan $100 \mathrm{ml}$ metanol dalam labu ukur $100 \mathrm{ml}$. Selanjutnya membuat larutan induk sampel ekstrak metanol buah nanas konsentrasi $1500 \mu \mathrm{g} / \mathrm{ml}$. Kemudian dibuat variasi konsentrasi $125 ; 250 ; 500 ; 1000 \mu \mathrm{g} / \mathrm{ml}$ dari larutan induk. Pengukuran aktivitas antioksidan dengan mengambil $6 \mathrm{ml}$ larutan standar dari berbagai konsentrasi dan ditambahkan masing masing $4 \mathrm{ml}$ larutan $\mathrm{DPPH}$, kemudian dihomogenkan dan diinkubasi pada suhu ruang dan gelap selama 30 menit. 5 - 10 menit sebelum waktu inkubasi berakhir, setiap larutan dihomogenkan menggunakan vortex selama 10 detik. Hasil dibaca memakai spektrofotometer UV-Vis pada $516 \mathrm{~nm}$. Kontrol yang digunakan adalah asam askorbat dan metanol sebagai blanko.

\section{Pengujian sitotoksisitas}

Uji sitotoksisitas pada penelitian ini merupakan modifikasi dari metode Junedi (2014). Pengujian diawali dengan menyiapkan 96-well plate kemudian menanam sel T-47D pada $100 \mathrm{ml}$ medium RPMI dengan jumlah sel $5 \times 10^{4} \mathrm{sel} /$ sumuran. Larutan diresuspensi kembali setiap mengisi sebanyak 12 sumuran agar sel tetap homogen. Sel kemudian diinkubasi pada inkubator $\mathrm{CO}_{2}$ selama semalam dengan tujuan memulihkan sel setelah setelah proses pemanenan.

Sel diperlakukan dengan membalik plate dan sisa cairan pada sumuran ditiriskan menggunakan tisu. Sel dicuci menggunakan $100 \mu \mathrm{L}$ PBS $1 \mathrm{x}$ sebelum diberi perlakuan dengan seri konsentrasi triplo pada rentang 125;250;500;1.000 $\mu \mathrm{g} / \mathrm{ml}$. Sel kemudian dimasukkan ke inkubator $\mathrm{CO}_{2}$ selama 24 jam. Kontrol positif menggunakan Cisplatin.

Pewarnaan MTT dilakukan dengan mengambil media kultur dengan kandungan senyawa uji, selanjutnya dicuci menggunakan $100 \mu \mathrm{l}$ PBS 1x. $100 \mu \mathrm{l}$ MTT ditambahkan ke dalam media kultur konsentrasi $0.5 \mathrm{mg} / \mathrm{ml}$. Plate dimasukkan ke inkubator $\mathrm{CO}_{2}$ selama 4 jam. Penghentian reaksi MTT dengan cara menambahkan SDS $10 \%$ (dalam $0.01 \mathrm{~N} \mathrm{HCl}$ ) pada 
media yang sebelumnya sudah mengandung MTT sebanyak $100 \mu$ l. Selanjutnya dilakukan proses inkubasi pada suhu kamar selama semalam dengan kondisi plate dilapisi aluminium foil. Untuk melarutkan formazan, plate digoyangkan pada shaker $100 \mathrm{rpm}, 10$ menit. Absorbansi dibaca menggunakan ELISA reader pada panjang gelombang $570 \mathrm{~nm}$. Sel hidup bereaksi dengan MTT dan menghasilkan warna ungu.

\section{Prosedur Analisis}

Analisis data untuk menentukan nilai $I_{50}$ menggunakan Microsoft Excell 2010 (Widowati dkk., 2015; Junedi, 2014).

Berikut adalah perhitungan nilai $\mathrm{IC}_{50}$ aktivitas antioksidan :

a. $\%$ Inhibisi = absorbansi blanko-absorbansi sampel $\times 100 \%$

b. Pembuatan kurva kalibrasi absorbansi blanko

Pembuatan kurva kalibrasi dengan cara memasukkan data konsentrasi $(x)$ dan \%inhibisi (y). Kemudian diperoleh persamaan regresi dari kurva kalibrasi.

c. $\mathrm{IC}_{50}$

Dari persamaan regresi, $y=a x+b$, dapat diperoleh nilai $\mathrm{IC}_{50}=50-b a$

(Primurdia dan Kusnadi, 2014); Widowati, dkk., 2015)

Berikut adalah perhitungan nilai $\mathrm{IC}_{50}$ sitotoksisitas :

Persentase sel hidup $=($ absorbansi perlakuan - absorbansi kontrol media $) \times 100 \%$ (absorbansi kontrol sel - absorbansi kontrol media)

Pembuatan kurva kalibrasi dan perhitungan nilai $I_{50}$ sesuai dengan perhitungan pada aktivitas antioksidan (Junedi, 2014).

\section{HASIL DAN PEMBAHASAN}

\section{Uji Aktivitas Antioksidan}

Proses ekstraksi dari $100 \mathrm{~g}$ sampel buah nanas menghasilkan rendemen sebesar 12 g. Buah nanas mengandung sumber antioksidan seperti senyawa fenolik serta flavonoid, dimana memiliki potensi sebagai antikanker (Hatam dkk., 2013; Pambudi, 2017; Lu dkk., 2014; Ferreira dkk., 2016). Senyawa fenolik merupakan fitokimia dimana seluruh zat terbuat dari derivat senyawa fenol. Kandungan senyawa fenolik pada buah nanas berfungsi sebagai antioksidatif karena mengandung antioksidan, serta sebagai antikanker dan antiinflamasi (Mann dan Truswell, 2012).

Pelarut metanol lebih efisien dalam mengekstrak senyawa fenolik dengan berat molekul yang rendah seperti asam fenolik, dimana asam fenolik merupakan senyawa fenolik utama yang berada pada nanas (Rasheed dkk., 2012). Sampel selanjutnya diuji aktivitas antioksidan menggunakan metode DPPH. Diperoleh hasil penghambatan radikal bebas tertinggi sebesar $32.7 \%$ pada konsentrasi $1000 \mu \mathrm{g} / \mathrm{ml}$ sampel metanol buah nanas (Tabel 1), dengan nilai $I_{50}$ yaitu $1549.88 \mu \mathrm{g} / \mathrm{ml}$ (Tabel 3). Kontrol yang digunakan adalah Vitamin $\mathrm{C}$ dengan nilai penghambatan tertinggi pada konsentrasi $2 \mu \mathrm{g} / \mathrm{ml}$ sebesar $90.64 \%$ (Tabel 2) dan nilai $I_{50}$ yaitu $1.17 \mu \mathrm{g} / \mathrm{ml}$.

Tabel 1. Persentase Penghambatan Radikal Bebas Ekstrak Metanol Buah Nanas

\begin{tabular}{ccccc}
\hline Sampel & \multicolumn{4}{c}{ Konsentrasi $(\boldsymbol{\mu g} / \mathbf{m l})$} \\
\cline { 2 - 5 } & $\mathbf{1 2 5}$ & $\mathbf{2 5 0}$ & $\mathbf{5 0 0}$ & $\mathbf{1 0 0 0}$ \\
\hline $\begin{array}{c}\text { Ekstrak Metanol } \\
\text { Buah Nanas }\end{array}$ & $5.52 \pm 0.66$ & $8.70 \pm 0.80$ & $17.30 \pm 0.48$ & $32.70 \pm 0.80$ \\
\hline
\end{tabular}


Tabel 2. Persentase Penghambatan Radikal Bebas Vitamin C

\begin{tabular}{cccc}
\hline Sampel & \multicolumn{3}{c}{ Konsentrasi $(\boldsymbol{\mu g} / \mathbf{m l})$} \\
\cline { 2 - 4 } & $\mathbf{0 , 5}$ & $\mathbf{1}$ & $\mathbf{2}$ \\
\hline Asam Askorbat & $14.61 \pm 2.25$ & $44.94 \pm 18.70$ & $90.64 \pm 1.29$ \\
\hline Tabel 3. Nilai IC 50 Aktivitas Antioksidan menggunakan DPPH & $\mathbf{R}^{\mathbf{2}}$ & $\begin{array}{c}\mathbf{I C}_{50} \\
(\boldsymbol{\mu g} / \mathbf{m l})\end{array}$ \\
\hline Sampel & Persamaan Linier & 0.99 & 1549.88 \\
\hline $\begin{array}{c}\text { Ekstrak Metanol } \\
\text { Buah Nanas } \\
\text { Vitamin C }\end{array}$ & $\mathrm{y}=0.03 \mathrm{x}+1.33$ & 0.99 & 1.17 \\
\hline
\end{tabular}

Sifat antioksidan berdasarkan nilai $\mathrm{IC}_{50}$ dibagi menjadi 4 , yaitu jika nilai $\mathrm{IC}_{50}<50 \mu \mathrm{g} / \mathrm{ml}$ bermakna sangat kuat; $\mathrm{IC}_{50} 50-100 \mu \mathrm{g} / \mathrm{ml}$ bermakna kuat; IC ${ }_{50} 101-150 \mu \mathrm{g} / \mathrm{ml}$ bermakna sedang, dan $\mathrm{IC}_{50} 150-200 \mathrm{\mu g} / \mathrm{ml}$ bermakna lemah (Tristantini dkk.. 2016). Hasil IC 50 pada penelitian ini adalah $1549.88 \mu \mathrm{g} / \mathrm{ml}$ dan aktivitas antioksidannya tergolong sangat lemah. Senyawa fenolik yang didapatkan dari buah nanas dipengaruhi oleh bagian buah nanas, dimana didapati bahwa senyawa fenolik paling banyak dijumpai pada kulit dan batang, sedangkan pada daging buah ditemukan senyawa fenolik paling sedikit (Rasheed dkk., 2012).

Konsentrasi pelarut metanol berpengaruh terhadap senyawa fenolik yang didapat. Pelarut metanol $50 \%$ memiliki konsentrasi ekstraksi senyawa fenolik tertinggi pada nanas jenis Morris yaitu sebesar $53.8 \pm 0.7 \mathrm{mg} \mathrm{GAE} / 100 \mathrm{~g}$ dibandingkan dengan metanol $70 \%$ (49.2 $\pm 0.4 \mathrm{mg} \mathrm{GAE} / 100 \mathrm{~g})$. Oleh karena itu, sebaiknya bisa menambahkan campuran air pada pelarut metanol untuk memaksimalkan ekstraksi senyawa fenolik sehingga bisa meningkatkan aktivitas antioksidan (Yuris dan Siow, 2014).

\section{Uji Sitotoksisitas}

Hasil nilai $\mathrm{IC}_{50}$ penghambatan proliferasi ekstrak metanol buah nanas terhadap sel kanker payudara T-47D adalah sebesar $741.46 \mu \mathrm{g} / \mathrm{ml}$ (Tabel 6). Cisplatin digunakan sebagai kontrol positif dengan nilai $\mathrm{IC}_{50}$ ialah $8.61 \mu \mathrm{g} / \mathrm{ml}$.

Tingkatan sitotoksisitas dibagi menjadi 3 kelompok, yaitu sitotoksisitas potensial bila $\mathrm{IC}_{50}<100 \mu \mathrm{g} / \mathrm{ml}$, sitotoksisitas moderat bila $\mathrm{IC}_{50} 100-1000 \mu \mathrm{g} / \mathrm{ml}$, dan tidak toksik bila > $1000 \mu \mathrm{g} / \mathrm{ml}$. Senyawa dengan sitotoksisitas potensial dapat dimanfaatkan sebagai agen antikanker. Sedang senyawa dengan sitotoksisitas moderat bisa berfungsi sebagai agen kemoprevensi, dimana hanya dapat menghambat dan mencegah perkembangan sel kanker. Penelitian ini menunjukkan hasil sitotoksisitas ekstrak metanol buah nanas bersifat moderat pada sel kanker payudara T-47D.

Tabel 4. Hasil Penghambatan Proliferasi oleh Ekstrak Metanol Buah Nanas pada Sel Kanker Payudara T-47D

\begin{tabular}{ccccc}
\hline Sampel & \multicolumn{4}{c}{ Konsentrasi $(\boldsymbol{\mu g} / \mathbf{m l})$} \\
\cline { 2 - 5 } & $\mathbf{1 2 5}$ & $\mathbf{2 5 0}$ & $\mathbf{5 0 0}$ & $\mathbf{1 0 0 0}$ \\
\hline $\begin{array}{c}\text { Ekstrak Metanol } \\
\text { Buah Nanas }\end{array}$ & $31.52 \pm 6.56$ & $40.36 \pm 1.26$ & $46.02 \pm 1.11$ & $55.23 \pm 4.11$ \\
\hline
\end{tabular}

Antioksidan berperan untuk menangkap radikal bebas agar kanker tidak dapat berkembang, baik pada tahap inisiasi, promosi maupun progresi. Fitokimia mengandung antioksidan yang berfungsi sebagai kemopreventif maupun kuratif dimana sebagai antikanker, dapat membantu agen kemoterapi dalam membentuk efek pro-oksidan, sehingga kematian sel kanker semakin meningkat dan proliferasi sel kanker dapat dihambat (Chikara dkk., 2018). 
Flavonoid merupakan salah satu antioksidan yang berperan pada penghambatan sel kanker dengan cara berikatan pada death receptor (TNF-R) dan Fas Associated Death Domain (FADD) yang membentuk kompleks Death Inducing Signaling Complex (DISC). Kompleks ini akan mengaktifkan caspase 8 yang menstimulasi protein Bid yang akan merangsang Bax ke dalam membran mitokondrial dan mengeluarkan molekul proapoptotik yaitu Sitokrom C. Sitokrom C mengikat Apoptosis Activating Factor 1 (APAF-1) sehingga membentuk apoptosom. Apoptosom tersebut kemudian mengaktivasi terjadinya proses apoptosis (Meiyanto dan Endah, 2005; Monastrio, 2004; Sak, 2014; Sari, 2018).

Tabel 5. Hasil Penghambatan Proliferasi oleh Cisplatin terhadap Sel Kanker Payudara T-47D

\begin{tabular}{ccccc}
\hline Sampel & \multicolumn{4}{c}{ Konsentrasi $(\boldsymbol{\mu g} / \mathbf{m l})$} \\
\cline { 2 - 5 } & $\mathbf{3}$ & $\mathbf{6}$ & $\mathbf{9}$ & $\mathbf{1 2}$ \\
\hline Cisplatin & $9.78 \pm 3.71$ & $23.10 \pm 1.11$ & $60.73 \pm 0.96$ & $73.19 \pm 0.23$ \\
\hline \multicolumn{2}{c}{ Tabel 6. Nilai IC $_{50}$ Uji Sitotoksisitas pada Sel Kanker Payudara T-47D } \\
\hline Sampel & Persamaan Linier & $\mathbf{R}^{2}$ & $\begin{array}{c}\mathbf{I C}_{50} \\
(\boldsymbol{\mu} \mathbf{g} / \mathbf{m l})\end{array}$ \\
\hline $\begin{array}{c}\text { Ekstrak Metanol } \\
\text { Buah Nanas } \\
\text { Cisplatin }\end{array}$ & $\mathrm{y}=0.02 \mathrm{x}+31.69$ & 0.93 & 741.46 \\
\hline
\end{tabular}

Jenis pelarut yang dipilih menentukan hasil sitotoksisitas. Pada penelitian terhadap buah jambu wer (Prunus persica (L.) Batsch) hasil uji sitotoksitas terbaik diperoleh dengan menggunakan pelarut kloroform (Rahmatika, 2019). Uji sitotoksisitas juga dilakukan pada jenis buah Brucea javanica (L.) MERR pada sel kanker payudara T-47D dengan berbagai jenis pelarut. Hasil uji terbaik ditunjukkan pada pelarut kloroform dengan nilai $\mathrm{IC}_{50}$ sebesar $109 \mu \mathrm{g} / \mathrm{ml}$ (Wardoyo dkk., 2011).

Buah nanas mengandung flavonoid yang memiliki efek antioksidan, antiinflamasi, dan aktivitas apoptosis, sehingga berpotensi sebagai antikanker (Lanham-New dkk., 2011). Flavonoid dapat merangsang apoptosis melalui penurunan regulasi anti apoptosis (Bcl2 dan $\mathrm{BCl}-\mathrm{xl}$ ) sehingga dapat memicu apoptosis pada sel kanker (Zhang, 2019; Sarmoko dan Larasati, 2012). Flavonoid juga dapat menghambat enzim yang dapat mengaktivasi karsinogenik, dengan cara menghambat ekspresi gen CYP1A1 (enzim sitokrom 450) yang berfungsi untuk membantu metabolisme toksin, sehingga kerusakan DNA dapat diminimalisir dan mengembalikan keseimbangan seluler dan genetik (Kurniasari dkk., 2017).

Sifat sitotoksisitas pada suatu ekstrak tidak selalu berhubungan secara linier dengan aktivitas antioskidannya. Pada penelitian ini, ekstrak metanol buah nanas menunjukkan aktivitas antioksidan yang sangat lemah dan sitotoksisitas moderat terhadap sel T-47D. Hal ini sejalan dengan hasil penelitian ekstrak etanol Curcuma mangga yang memiliki aktivitas antioksidan yang sangat lemah $(277.79 \mu \mathrm{g} / \mathrm{ml})$ dengan sitotoksisitas pada sel kanker T-47D yang bersifat moderat $(404.76 \mu \mathrm{g} / \mathrm{ml})$. Hal ini dipengaruhi oleh kandungan fitokimia yang terkandung dalam sampel yang diuji dan reaksinya terhadap sel kanker T-47D (Widowati dkk., 2011). 


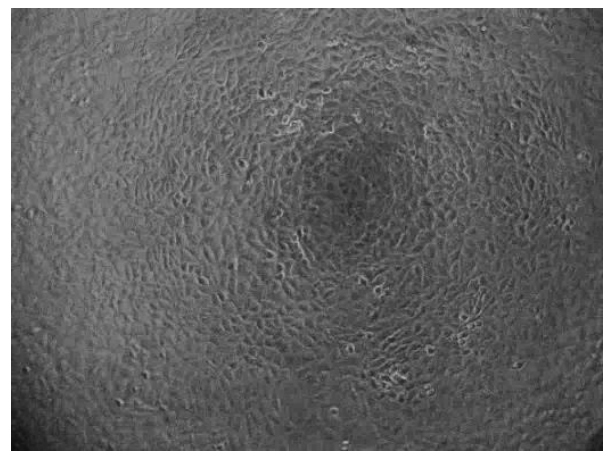

(a)

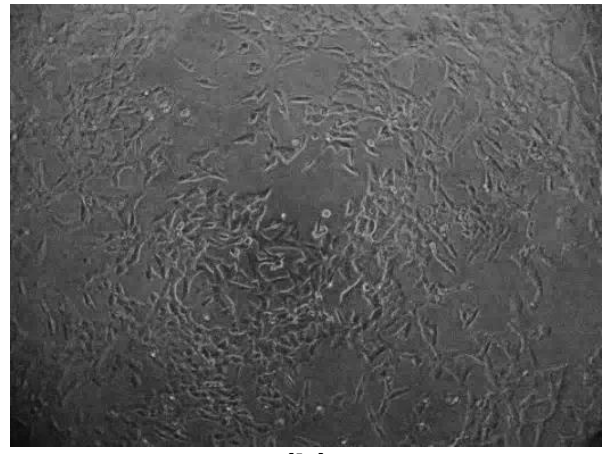

(b)

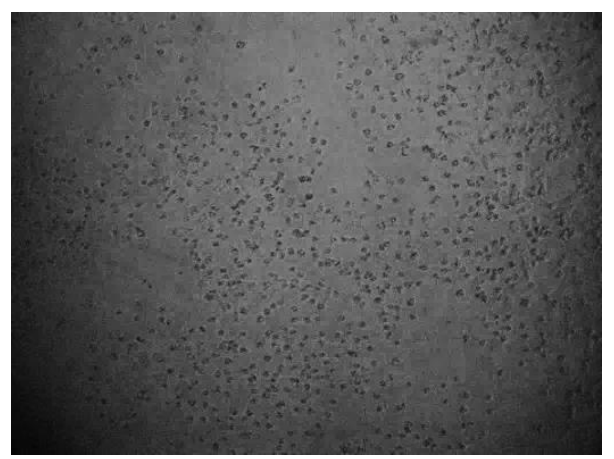

(c)

Gambar 1. Foto sel kanker payudara T-47D yang diperlakukan selama 24 jam.

a) Kontrol sel tanpa perlakuan menunjukkan morfologi sel memanjang seperti epitel dan tingkat konfluensi yang tinggi. b) Ketika diberi perlakuan dengan $1000 \mu \mathrm{g} / \mathrm{ml}$ ekstrak metanol buah nanas, sel mengalami banyak kematian ditunjukkan dengan tingkat konfluensi yang berkurang. c) Perlakuan dengan $2 \mu \mathrm{g} / \mathrm{ml}$ Cisplatin menunjukkan hampir tidak terdapat sel yang hidup hanya sisa-sisa debris sel tampak. Foto sel diambil menggunakan mikroskop inverted dengan perbesaran 100X.

\section{SIMPULAN}

Dapat disimpulkan bahwa aktivitas antioksidan ekstrak metanol buah nanas menggunakan metode DPPH menunjukkan hasil yang sangat lemah dan sitotoksisitas ekstrak metanol buah nanas pada sel kanker payudara T-47D termasuk dalam kategori sitotoksisitas moderat dengan demikian memiliki potensi sebagai agen kemopreventif.

\section{UCAPAN TERIMA KASIH}

Ucapan terima kasih penulis ucapkan kepada "Tim Riset Nanas". Terimakasih juga disampaikan untuk Laboratorium Kimia Universitas Tribhuwana Tunggadewi, Laboratorium Biokimia Universitas Brawijaya dan Laboratorium Kultur Sel LAPTIAB BPPT Puspiptek Serpong.

\section{DAFTAR PUSTAKA}

Aune, D., Chan, DMS., Vieira, AR., Rosenblatt, DAN., Vieira, R., Greenwood, DC., Norat. T. 2012. Fruits, Vegetables and Breast Cancer Risk: A Systematic Review and Metaanalysis of Prospective Studies. Breast Cancer Res Treat 134: 479. 
Chikara, S., Nagaprashantha, LD., Singhal, J., Horne, D., Awasthi, S., Singhal, SS. 2018. Oxidative Stress and Dietary Phytochemicals: Role in Cancer Chemoprevention and Treatment. Cancer Letters 413: 122-134.

Clarke, S.D and Jump, D.B. 1994. Dietary Polyunsaturated Fatty Acid Regulation of Gene transcription. Annu Rev Nutr 14:2, 83-98

Eastwood, M. 2003. Principle Of Human Nutrition. Blackwell Science. UK

Ferreira, EA., Siqueira, HE., Hermes, VS., Rios, ADO. 2016. Bioactive Compounds and Antioxidant Activity Of Pineapple Fruit of Different Cultivars. Rev. Bras. Frutic., vol 38 (3): e-146.

Hatam, SF., Suryanto, E., Abidjulu, J. 2013. Aktivitas Antioksidan dari Ekstrak Kulit Nanas (Ananas comosus (L) Merr). J. IImiah Farmasi-UNSRAT Vol. 2 (1): 8-11.

IARC (International Agency for Research on Cancer). 2012. GLOBOCAN 2012: Estimated Cancer Incidence, Mortality, and Prevalence World Wide in 2012. WHO

Junedi, S. 2014. Prosedur Tetap Uji Sitotoksik Metode MTT. Cancer Chemoprevention Research Center Fakultas Farmasi UGM. Yogyakarta.

Kelvin, JF dan Tyson, LB. 2011. Tanya-Jawab Mengenai Gejala Kanker dan Efek Samping Pengobatan Kanker. Edisi kedua. PT Indeks. Jakarta Barat

Kemenkes RI. 2018. Riset Kesehatan Dasar. Balitbang Kemenkes RI. Jakarta.

Kurniasari, FN., Harti, LB., Ariestiningsih, AD., Wardhani, SO., Nugroho, S . 2017. Buku Ajar Gizi dan Kanker. UB Press. Malang

Lanham-New, SA., Macdonald, IA., Roche, HM. 2011. Metabolisme Zat Gizi. Buku Kedokteran EGC. Jakarta.

Lu, XH., Sun, DQ., Wu, QS., Liu, SH., Sun, GM. 2014. Physico-Chemical Properties, Antioxidant Activity and Mineral Contents of Pineapple Genotypes Grown in China. Molecules, 19, 8518-8532.

Mann, J., Truswell, S. 2012. Buku Ajar Ilmu Gizi. Buku Kedokteran EGC. Jakarta.

Meiyanto, E. dan Endah P. 2005. Efek Antiproliferatif dan Apoptosis Fraksi Fenolik Ekstrak Etanolik Daun Gynura procumbens (Lour.) Merr. Terhadap Sel HeLa. Artocarpus, 5(2):74-80.

Pambudi, Y. B. 2017. Uji Aktivitas Antioksidan dan Penetapan Kadar Bromelain terhadap Bovine Serum Albumin (BSA) dari Ekstrak Kulit Buah Nanas. Skripsi. Fakultas Farmasi. Universitas Sanata Dharma. Yogyakarta.

Primurdia, EG dan Kusnadi, J. 2014. Aktivitas Antioksidan Minuman Probiotik Sari Kurma (Phoenix dactilyfera L.) dengan Isolat L. plantarum dan L. casei. Jurnal Pangan dan Agroindustri Vol.2 No.3 p.98-109

Rahmatika, F. S. 2019. Aktivitas Antikanker Ekstrak Dan Fraksi Buah Jambu Wer (Prunus persica (L.) Batsch) Terhadap Sel T47d Secara In Vitro. Skripsi. Jurusan Farmasi, Fakultas Kedokteran dan IImu Kesehatan. Universitas Islam Negeri Maulana Malik Ibrahim Malang.

Rasheed, AA., Cobham, El., Zighami, M., Ong, SP. 2012. Extraction Of Phenolic Compounds From Pineapple Fruit. ISPDFVF 2012, University of Nottingham, Malaysia Campus.

Rejeki, ES. dan Ningsing, D. 2010. Uji Aktivitas Antoksidan Buah Nanas terhadap Radikal Bebas. Biomedika Vol.3 (2)

Sak, K. 2014. Cytotoxicity of Dietary Flavonoids on Different Human Cancer Types. Pharmacogonosy Reviews, 8(16):122-146.

Sari, LM. 2018. Apoptosis: Mekanisme Molekuler Kematian Sel. Cakradonya Dental Journal, 10(2): 65-70

Sarmoko dan Larasati. 2012. Regulasi Siklus Sel. CCRC. Yogyakarta.

Tristantini, D., Ismawati, A., Pradana, BT., Jonathan, JG. 2016. Pengujian Aktivitas Antioksidan Menggunakan Metode DPPH pada Daun Tanjung (Mimusops elengi L). Prosiding Seminar Nasional Teknik Kimia "Kejuangan", Pengembangan Teknologi Kimia untuk Pengolahan Sumber Daya Alam Indonesia, ISSN 1693-4393. 
Urdaci, MC., Pinchuk, IV., Moratalla, NL \& Irujo, JJM. 2004. Flavonoids Induce Apoptosis in Human Leukemia U937 Cells Through Caspase- and Caspase-Calpain-Dependent Pathways, Nutrition and Cancer, 50(1):90-100.

Wardoyo, ERP., Nugroho, LH., Santosa, Moeljopwairo, S. 2011. Efek Sitotoksik Ekstrak Kloroform, Methanol dan Air Buah Brucea javanica (L.) Merr. terhadap Sel Kanker Payudara (T47D). Berk. Penel. Hayati Edisi Khusus 4D : 13-16.

WHO. 2018. Cancer. https://www.who.int/news-room/fact-sheets/detail/cancer. Tanggal akses: 25/01/2019.

Widowati, W., Mozef, T., Risdian, C., Ratnawati, H., Tjahjani, S., Sandra, F. 2011. The Comparison of Antioxidative and Proliferation Inhibitor Properties of Piper betle L., Catharanthus roseus [L] G.Don, Dendrophtoe petandra L., Curcuma mangga Val. Extracts on T47D Cancer Cell Line. International Research Journal of Biochemistry and Bioinformatics Vol. 1(2): 022-028.

Widowati, W., Widyanto, RM., Laksmitawati, DR., Erawijantari, PT., Wijaya, L and Sandra, F. 2015. Phytochemical, Free Radical Scavenging and Cytotoxic Assay of Cucumis Melo L. Extract and $\beta$-Carotene. Journal of Advanced Agricultural Technologies Vol. 2 (2): 114-119.

Yuris, A., Siow, L. F. 2014. A Comparative Study of The Antioxidant Properties of Three Pineapple (Ananas comosus L.) Varieties. Journal of Food Studies Vol. 3 (1): 40 56.

Zhang, H., Hu, J., Fu, R., Fu, R., Liu, X., Zhang, Y., Li, J., Liu, L., Li, Y., Deng, Q., Luo, Q., Ouyang, Q \& Gao, N. 2018. Flavonoids Inhibit Cell Proliferation and Induce Apoptosis and Autophagy through Down Regulation of PI3Ky Mediated $\mathrm{PI3K} / \mathrm{AKT} / \mathrm{mTOR} / \mathrm{p} 70 \mathrm{S6K} / \mathrm{ULK}$ Signaling Pathway in Human Breast Cancer Cells. Sci Rep 8, 11255. 